\title{
PERJANJIAN BELI KEMBALI (BUY BACK GUARANTEE) ANTARA PENGEMBANG DAN BANK DALAM PENYELESAIAN MASALAH KREDIT MACET
}

\author{
Disusun Oleh : \\ Retno Wahyurini Dominika \\ Endang Sri Kawuryan \\ PT. Citra Sekawan Mandiri \\ Perum Citra Sekawan Mandiri Blok C No. 2 Wilayut Sukodono \\ Email : dominikaretno593@gmail.com
}

\begin{abstract}
Abstrak
Penelitian ini bertujuan mengetahui kepentingan pengembang dan praktik di bidang kenotariatan untuk menganalisa bentuk hubungan hukum dan tanggung gugat antara Debitur, Bank dan Pengembang yang merupakan subyek dalam akta perjanjian beli kembali (buy back guaratee) agar mampu memberikan perlindungan hukum bagi pengembang dalam hal memiliki kembali obyek jaminan. Dalam penelitian ini penulis menggunakan metode pendekatan Normatif, yang menurut Peter Mahmud Marzuki, "Penelitian hukum adalah suatu penelitian yang menganalisis situasi faktual dan menerapkan doktrin-doktrin hukum yang telah terbentuk". Bersandar pada teori keadilan dan perlindungan hukum, azas asas dalam hukum jaminan dengan tidak meninggalkan asas asas dalam teori Perjanjian dan pelaksanaan prinsip kehati hatian dalam dunia perbankan yang mendasari munculnya Perjanjian beli kembali (buy back guarantee).

Akhirnya dalam penelitian ini penulis menyimpulkan dalam perjanjian pembelian rumah dengan fasilirtas KPR terjadi tiga hubungan hukum, pertama hubungan yang terjadi antara bank dalam hal ini selaku kreditur dengan pihak debitur (pembeli) hubungan yang terjadi ditetapkan dalam suatu perjanjian kredit dengan jaminan tanggung gugat bank, kedua hubungan hukum antara pihak bank selaku kreditur dengan pengembang, hubungan hukum yang terbentuk adalah perjanjian "buy back guarantie" dalam hal ini pengembang mengikatkan diri dan bertanggung jawab menjamin pembayaran seluruh dana yang diberikan kepada debitur (pembeli) oleh bank dalam hal kreditur telah melalaikan kewajibannya, ketiga hubungan antara pengembang dengan debitur (pembeli) dalam hal ini hubungan yang timbul adalah perjanjian subrogasi, pembayaran seluruh hutang debitur oleh pengembang kepada bank menimbulkan subrogasi yaitu pergantian hak-hak si berpiutang (bank) oleh pihak ketiga (pengembang) yang membayar kepada si berpiutang (bank) tersebut oleh karena itu sebagai Bentuk perlindungan hukum bagi pengembang untuk memiliki kembali obyek jaminan jika pengembang melaksanakan isi dari perjanjian beli kembali (buy back guarantee), adalah Akta Subrogasi
\end{abstract}



Kata Kunci : Jaminan membeli kembali (Buy Back guarantee), Pengembang, Subrogasi

\section{Latar Belakang Masalah}

Batasan perjanjian yang diberikan oleh Kitab Undang-udang Hukum Perdata dalam Pasal 1313 disebutkan, "Suatu perjanjian adalah suatu perbuatan dengan mana satu orang atau lebih mengikatkan dirinya terhadap satu orang lain atau lebih". Sudikno Mertokusumo juga memberi batasan bahwa perjanjian itu suatu hubungan hukum antara dua pihak atau lebih berdasarkan kata sepakat untuk menimbulkan akibat hukum. ${ }^{1}$ Batasan terhadap "perjanjian" yang diberikan oleh Sudikno Mertokusumo lebih sesuai dengan kebutuhan praktik hukum, karena di dalamnya telah lebih dijelaskan unsur "hubungan hukum" dan "akibat hukum".

Istilah perjanjian (overeenkomst) ada kaitannya dengan pengertian perikatan (verbintenis), kedua-duanya merupakan unsur yang saling mengisi dalam membentuk suatu perjanjian. Vollmar mengartikan verbintenis sebagai perutangan (jika verbintenis itu menyangkut lapangan hukum harta kekayaan), sehingga untuk batasan perikatan dalam arti "perutangan" diberi batasan sebagai: "Sebuah hubungan hukum berdasarkan hubungan hukum dimana seseorang dapat mengharapkan suatu prestasi dari seseorang lain, jika perlu dengan perantaraan hakim". ${ }^{2}$

Meskipun terjemahan verbintennis dapat diartikan sebagai perutangan seperti dilakukan Vollmar, penggunaan istilah itu sangat terbatas sehingga untuk selanjutnya lebih cocok menggunakan istilah perikatan. Istilah perikatan adalah juga mencakup perutangan. Hubungan yang terjadi antara perjanjian dengan perikatan, Subekti menjelaskan bahwa "perikatan merupakan bentuk abstrak sedangkan perjanjian merupakan suatu peristiwa konkret. ${ }^{3}$ Peristiwa yang konkret itu dapat dilihat dalam suatu kontrak.

Perjanjian dan undang-undang dalam sistem hukum perikatan merupakan suatu sumber perikatan yang artinya: "semua perikatan dilahirkan baik karena

${ }^{1}$ Sudikno Mertokusumo, Mengenal Hukum, Liberty, Yogyakarta, 1988, hlm. 97.

${ }^{2}$ H.F.A. Vollmar, Pengantar Studi Hukum Perdata, Jilid II, Rajawali, Jakarta, 1984, hlm. 63.

${ }^{3}$ R. Subekti, Hukum Perjanjian, Intermasa, Jakarta, 1987, hlm. 3. 

perjanjian maupun karena undang-undang". Istilah perjanjian sebagai terjemahan "overeenkomst" telah diterima secara luas dalam kepustakaan di Indonesia, dan untuk terjemahan "verbintenissen" digunakan istilah perikatan, terjemahan yang memudahkan pemahaman tentang pengertian kedua istilah hukum tersebut.

Menyangkut pengertian perikatan Schut menjelaskan bahwa istilah itu digunakan dalam dua pengertian yang erat hubungannya satu sama lain yaitu:

a. Sebagai hubungan hukum bahwa salah seorang berhak untuk sesuatu dan yang seorang lagi berkewajiban mengenai sesuatu.

b. Sebagai suatu kewajiban hukum yaitu suatu kewajiban hukum yang dihadapkan dengan sesuatu wewenang untuk mengadakan tuntutan. ${ }^{1}$

Bertitik tolak pada pengertian itu, Schut memberikan pengertian terhadap perikatan itu sebagai hubungan-hubungan hak-hak kebendaan (vermogensrechtslijke betrekingen) antara dua orang dalam hal yang seorang (kreditur) dapat menuntut dari yang seorang lagi (debitur) pelaksanaan suatu prestasi atau kewajiban memberikan jaminan. ${ }^{2}$

Terkait dengan jaminan, lembaga yang biasanya menerima penjaminan salah satunya adalah bank. Bank adalah lembaga keuangan yang berwenang melakukan pelayanan dalam masyarakat di bidang keuangan, penyimpanan maupun pembiayaan (yang biasa disebut kredit). Dalam menunjang dunia usaha terutama di bidang property, kredit adalah penunjang utama sebab sebagian pembayaran yang dilakukan oleh Pembeli adalah menggunakan fasilitas kredit dari bank, Kredit Pemilikan Rumah (KPR) Didasari oleh prinsip kehati-hatian bank dalam memberikan fasilitas Kredit Pemilikan Rumah (KPR), maka dibuatlah perjanjian kerjasama antara Pengembang dan Bank yang isinya adalah bahwa pengembang bersedia membeli kembali unit rumah yang telah dijual kepada konsumen yang di sisi lain adalah debitur dari bank pemberi KPR, jika konsumen/debitur tersebut cidera janji dan tidak mampu membayar angsuran

${ }^{1}$ H.P. Pangabean, Praktik Standard Contract (Perjanjian Baku) Dalam Perjanjian Kredit Perbankan), Alumni, Bandung, 2012, hlm. 60.

${ }^{2}$ Ibid. 

pada bank secara berturut turut dalam kurun waktu tertentu sesuai dengan perjanjian.

Dalam praktek perjanjian Jual beli dengan hak membeli kembali penjual (pemilik semula) dalam hal ini memiliki atau diberikan hak untuk membeli kembali barang yang telah dijual tersebut, hal ini diatur dalam KUHPer Pasal 1519. Banyak hal yang mendorong para pihak untuk melakukan suatu perjanjian jual beli dengan hak membeli kembali, nilai tertentu dari pihak penjual terhadap objek yang menjadikan alasan timbulnya suatu perjanjian jual beli dengan hak membeli kembali.

Dapat dikatakan perjanjian jual beli dengan hak membeli kembali merupakan bentuk jual beli semu karena dalam hal ini sebenarnya yang terjadi adalah hutang-piutang, disini seseorang yang membutuhkan dana perjanjian yang dibuat antara debitur dan kreditur adalah perjanjian jual beli dengan hak membeli kembali, akan tetapi rumah yang dijual tetap dalam penguasaan debitur (penjual). Secara konkrit dalam hukum sebenarnya yang terjadi bukan jual beli namun perjanjian hutang piutang dengan jaminan yang berbentuk seakan-akan lembaga gadai. Tujuannya dari perjanjian ini adalah guna memperkuat posisi kreditur baik terhadap debitur maupun terhadap pihak ketiga, dengan adanya akta jual beli walaupun dengan syarat membeli kembali sudah menjamin kepentingan kreditur atas pemenuhan hutang, apabila dikemudian hari barang agunan dipindahkan tagankan atau dibebani dengan hak-hak pihak ketiga oleh debitur, maka dalam hal ini kreditur dapat melakukan perlawanan atau verzet atas dasar hak milik yang dilandasi dengan jual beli.

Akan tetapi karena syarat pembuktiannya adalah berat dan perjanjian jual beli dengan hak membeli kembali mengenai tanah dan atau rumah selalu terjadi dengan suatu akta otentik sehingga bagi debitur yang dalam keadaan terdesak akan sulit membuktikan bahwa akta tersebut adalah tidak sah dan sering kali penjual atau debitur tidak berhasil untuk membuktikan bahwa yang sebenarnya terjadi adalah hutang piutang. Jadi, dapat dikatakan bahwa dalam perjanjian hutang piutang tersebut biasanya selalu terdapat keadaan yang tidak seimbang, sehingga salah satu pihak tidak bebas dalam menentukan kehendaknya dan dapat 

juga ditafsirkan terdapat penyalahgunaan keadaan/kesempatan atau pun penyalahgunaan kekuasaan ekonomis.

Dalam aturan UUPA tentang peralihan hak atas tanah dimana aturanaturan dalam UUPA banyak mengadop aturan hukum adat maka berdasar pada pasal 5 UUPA maka jual beli dengan hak membeli kembali mengenai tanah dan rumah akan batal demi hukum. Hal tersebut dilandasi bahwa dalam hukum adat tidak mengenal adanya perjanjian jual beli dengan hak membeli kembali perjanjian tersebut hanya dianggap sebagai perjanjian gadai saja.

Dalam perkembangannya di dunia pemasaran Property, Pengembang membutuhkan mitra kerja Lembaga Pembiayaan atau Bank sebagai pihak yang membiayai pihak Pembeli untuk membeli rumah dengan cara Kredit Pemilikan Rumah(KPR) Adapun pihak bank menyarankan pembuatan perjanjian hak beli kembali kepada pengembang karena bank merasa yakin bahwa pihak pengembang pasti lebih mengenal karakter dan kemampuan konsumennya yang diketahui pada saat pemesanan rumah. Sehingga pada saat Konsumen menggunakan Fasilitas KPR dari bank yang bersangkutan Bank mengharapkan pihak pengembang merupakan filter pertama bagi penyaringan calon debitur, dan bagi pengembang sendiri sebetulnya bentuk kerjasama yang dituang dalam perjanjian beli kembali ini tidaklah merugikan karena disamping mempermudah proses pembelian rumah melalui KPR dari bank yang telah bekerjasama tadi juga mampu meningkatkan reputasi perusahaan pengembang dan kalaupun harus membeli kembali unit rumah yang bermasalah tersebut jika dijual kembali di jangka waktu ke depan harganya sudah mengalami peningkatan yang signifikan. Namun, demikian Perjanjian Beli Kembali ini tidak diatur dalam KUHPerdata namun hanya sebagai kebiasaan yang sering dilakukan antara pihak bank dan pengembang dan selalu dilakukan dalam perjanjian di bawah tangan dan memiliki kelemahan untuk pelaksanaannya.

Bahwa meskipun telah dilengkapi dengan penandatanganan Surat Kuasa Membebankan Hak Tanggugan (SKMHT), Pengakuan Hutang dan Kuasa Menjual oleh Debitur, pada saat AKAD KREDIT, Karena Dalam pasal 15 ayat 1 UUHT telah dituliskan Bahwa SKMHT tidak memuat kuasa untuk melakukan 

perbuatan hukum lain selain membebankan Hak tanggungan serta tidak memuat kuasa substitusi maka dalam hal ini untuk pelaksanaan pembelian kembali unit rumah yang dalam masalah kredit macet oleh pengembang tetap harus menghadirkan debitur yang bersangkutan, padahal untuk masalah masalah kredit macet tersebut sebagian besar terjadi karena debitur sudah tidak pernah muncul dan tidak diketahui keberadaannya.

Notaris selalu menegaskan untuk menghadirkan debitur karena debitur telah menandatangani akta jual beli dan sertifikat telah balik nama menjadi nama debitur, sehingga pada akhirnya pengembang yang melaksanakan isi perjanjian Beli Kembali tidak mampu memiliki kembali dalam hal ini tidak mampu mebalik nama sertipikat kembali menjadi nama Pengembang dan apabila Pengembang tidak bersedia melaksanakan isi perjanjian beli kembali tersebut maka bank tetap mengalami kredit macet. Adanya beberapa ketentuan dalam Perjanjian Beli Kembali tersebut yang melanggar asas keseimbangan antara pihak bank dan pihak pengembang.

Dengan demikian dalam hal ada sengketa tentang perjanjian jual beli tanah dan atau rumah dengan hak membeli kembali dan perjanjian asal adalah perjanjian hutang piutang, maka debitur dengan mudah dapat meminta agar perjanjian jual beli tanah dan atau rumah dengan hak membeli kembali tersebut dinyatakan batal atau dibatalkan sebagaimana Putusan Mahkamah Agung RI No. Register 1082 K/PDT/2013 tanggal 13 Maret 2014, namun perjanjian beli kembali tetap digunakan dalam praktik oleh Notaris.

\section{Rumusan Masalah}

Beranjak dari latar belakang sebagaimana telah diuraikan di atas, maka dapat ditentukan 2 (dua) rumusan masalahnya sebagai berikut:

2.1. Hubungan hukum dan tanggung gugat pihak pengembang, bank, dan debitur/pembeli dalam perjanjian beli kembali (buy back guarantee)? 

2.2. Bentuk Perlindungan hukum bagi pengembang untuk Memiliki kembali obyek Jaminan jika pengembang melaksanakan isi dari Perjanjian Beli Kembali (buy Back Guarantee).

\section{Tujuan Penelitian}

Berdasarkan rumusan masalah tersebut di atas, maka penelitian ini bertujuan untuk:

3.1. Menganalisis hubungan hukum dan tanggung gugat pihak pengembang, bank, dan debitur dalam perjanjian beli kembali (buy back guarantee).

3.2. Menganalisis bentuk Perlindungan hukum bagi pengembang untuk Memiliki kembali obyek Jaminan jika pengembang melaksanakan isi dari Perjanjian Beli Kembali (buy Back Guarantee)

\section{Manfaat Penelitian}

Adapun penelitian ini diharapkan dapat memberikan manfaat sebagai berikut:

4.1. Secara teoritis untuk Kepentingan Akademis adalah menambah wawasan dalam khasanah keilmuan yaitu memberikan suatu analisis mengenai hubungan hukum dan tanggung gugat pihak pengembang, bank, dan debitur dalam perjanjian beli kembali (buy back guarantee).

4.2. Secara praktis bagi kepentingan praktek hukum di bidang kenotariatan, bagi lembaga perbankan maupun bagi pengembang yaitu memberikan suatu analisis dan saran praktis mengenai bentuk perlindungan hukum bagi pengembang untuk Memiliki kembali obyek Jaminan jika pengembang melaksanakan isi dari Perjanjian Beli Kembali (buy Back Guarantee)

\section{Metode Penelitian}

\subsection{Tipe Penelitian}

Tipe penelitian yang digunakan adalah penelitian hukum normatif, menurut Peter Mahmud Marzuki, "Penelitian hukum adalah suatu 

penelitian yang menganalisis situasi faktual dan menerapkan doktrindoktrin hukum yang telah terbentuk atau dengan merujuk kepada putusanputusan hakim terdahulu dalam perkara serupa, doktrin-doktrin hukum tersebut bukan tidak mungkin saling berbenturan, oleh karena itulah dengan penelitian hukum ini dilakukan kegiatan menimbang doktrin mana yang mempunyai relevansi dengan masalah yang dihadapi, dan keahlian semacam ini hanya didapatkan dari Fakultas Hukum". ${ }^{1}$ Dengan demikian dalam penelitian ini akan menitikberatkan penilaian pada perilaku hukum Debitur yang dijamin serta menganalisa perjanjian buy back guarantee yang dilakukan oleh Developer sebagai penjamin dan Bank sebagai Kreditur dalam akta perjanjian yang seharusnya memiliki kekuatan hukum untuk menyelesaikan masalah kredit macet. Sehingga akhirnya bisa ditemukan solusi yang seimbang antara pengembang dan Bank dalam menyikapi Debitur yang wanprestasi. Pada Bank Pemberi Kredit pada posisi yang lebih spesifik bahwa Debitur wanprestasi dan tidak diketahui keberadaannya sehingga dapat diketahui pula tentang kajian hukum jaminan dalam pelaksanaannya.

\subsection{Pendekatan Masalah}

Pendekatan masalah yang digunakan dalam penelitian ini adalah

Pendekatan perundang-undangan (Statue Aprrooach), Pendekatan

Konseptual (Conseptual Approach), dan Pendekatan kasus (Case Aprroach).

5.2.1 Pendekatan Perundang-undangan (statue aprroach) adalah pendekatan yang dilakukan dengan menggunakan legislasi dan regulasi. $^{2}$ Dengan demikian dalam pendekatan ini peneliti akan memahami hierarki, dan asas-asas dalam peraturan perundangundangan yang berkaitan dengan Perjanjian Buy back guarantee yaitu meliputi hukum perjanjian dan perikatan, hukum jual beli, serta

${ }^{1}$ Peter Mahmud Marzuki, Penelitian Hukum, Edisi Revisi, Kencana Prenada Media Group, Jakarta, 2013, hlm. 57.

${ }^{2}$ Ibid., hlm. 137.

62 JURNAL TRANSPARANSI HUKUM Volume 1, Nomor 1, Januari 2018, Halaman 55-78 
hukum jaminan, karena ketiga unsur hukum itu yang melekat dalam perjanjian buy back guarantee.

5.2.2 Pendekatan konseptual (conseptual aprroach) adalah pendekatan yang beranjak dari pandangan-pandangan dan doktrin-doktrin yang berkembang di dalam ilmu hukum. ${ }^{3}$ Pendekatan ini dilakukan manakala penelitian tidak beranjak dari aturan hukum yang ada, karena memang aturan hukumnya belum ada untuk masalah yang dihadapi, di mana perjanjian beli kembali (buy back guarantee) ini masih belum diatur secara khusus dalam undang-undang, namun ditemukan dalam praktik penyaluran kredit yang disertai dengan perjanjian beli kembali oleh pihak penjual dan bank, di mana pihak penjual di sini ditetapkan sebagai penjamin ataupun subrogate seperti yang diatur dalam KUHPerdata melainkan sebagai penjamin untuk membeli kembali barang (rumah) yang telah dijualnya kepada pembeli memlaui fasilitas kredit bank, sebab perjanjian buy back guarantee ini lahir berdasarkan itikad baik dalam asa kebebasan berkontrak.

5.2.3 Pendekatan Kasus (case aprroach) adalah pendekatan yang dilakukan dengan cara melakukan telaah terhadap kasus-kasus yang berkiatan dengan isu yang dihadapi yang telah menjadi putusan pengadilan yang telah mempunyai kekuatan hukum yang tetap. ${ }^{4}$ Dalam hal ini akan diteliti suatu kasus terkait buy back guarantee di mana pada kasus tersebut telah ditemukan alasan hukum yang digunakan oleh hakim untuk sampai kepada putusan (ratio decidendi) seperti yang tertulis dalam Keputusan Mahkamah Agung Register 1082 K/PDT/2013 tanggal 13 Maret 2014.

\section{Sumber Bahan Hukum}

Bahan hukum yang digunakan dalam penelitian ini terdiri atas Sumber Bahan Hukum Primer dan sumber bahan hukum sekunder: 
6.1 Sumber bahan hukum Primer terdiri atas bahan hukum yang bersifat autoritatif yaitu bahan hukum yang memiliki otoritas dan mengikat berupa peraturan-peraturan baik berupa peraturan dasar negara, konstitusi maupun perundang undangan lainnya. Bahan hukum Primer yang akan di gunakan dalam penelitian ini adalah:

a. "Kitab Undang-undang Hukum Perdata";

b. "Undang-undang Republik Indonesia Nomor 4 Tahun 1996 tentang Hak Tanggungan";

c. "Undang-undang Undang-undang Republik Indonesia Nomor 42 Tahun 1999 tentang Jaminan Fidusia”;

d. "Undang-undang Undang-undang Republik Indonesia Nomor 7 Tahun 1992 tentang Perbankan; dan perubahannya";

e. "Undang-undang Undang-undang Republik Indonesia Nomor 30 Tahun 2004 tentang Jabatan Notaris";

f. Putusan Mahkamah Agung Republik Indonesia No. Register 1082 K/PDT/2013 tanggal 13 Maret 2014”.

6.2 Sumber bahan hukum sekunder meliputi bahan bahan yang mendukung bahan hukum primer seperti hasil penelitian hukum, buku buku teks bidang hukum, artikel dan atau opini hukum, kamus hukum sumber lainnya yang mendukung bahan hukum primer termasuk di dalamnya buku tentang Ekonomi dan Perbankan yang ada kaitannya dengan Buy back guarantee.

\section{Teknik Pengumpulan dan Analisis Bahan Hukum}

Bahan Hukum Primer berupa Perundang-undangan dikumpulkan dengan metode inventarisasi dan kategorisasi. Bahan hukum sekunder dikumpulkan dengan sistem kartu catatan (card sistem) baik dengan kartu ikhtisar (memuat ringkasan tulisan sesuai aslinya, secara garis besar dan pokok gagasan yang memuat pendapat asli penulis), kartu kutipan (digunakan untuk memuat catatan pokok permasalahan) untuk memuat 

catatan pokok permasalahan), serta kartu ulasan (berisi analisis dan catatan khusus penulis).

Bahan hukum Primer dan bahan hukum sekunder yang telah dikumpulkan (inventarisasi) kemudian dikelompokkan dan dikaji dengan pendekatan perundan undangan guna memperoleh gambaran sinkronisasi dari semua bahan hukum. Selanjutnya dilakukan sistimatisasi dan klasifikasi kemudian dikaji serta dibandingkan dengan teori dan prinsip hukum yang dikemukakan oleh para ahli untuk akhirnya dianalisa secara normatif. ${ }^{1}$

\section{PEMBAHASAN DAN HASIL PENELITIAN}

\subsection{Hubungan hukum dan tanggung gugat pihak pengembang, bank,} dan debitur dalam perjanjian beli kembali (buy back guarantee).

\subsubsection{Pengertian dan teori perjanjian}

Menurut Subekti, "suatu perjanjian juga dinamakan persetujuan, karena dua pihak itu setuju untuk melakukan sesuatu". ${ }^{2}$ Pengaturan tentang perjanjian dapat ditemui dalam Buku III Bab II Pasal 1313 KUHPerdata yang berbunyi : "Suatu perjanjian adalah suatu perbuatan dengan mana satu orang atau lebih mengikatkan dirinya terhadap satu orang lain atau lebih".

Menurut Abdulkadir Muhammad, pengertian Perjanjian dalam Pasal 1313 KUHPerdata tersebut kurang tepat, karena ada beberapa kelemahan yang perlu dikoreksi adalah sebagai berikut:

1) Hanya menyangkut sepihak saja: Hal ini dapat diketahui dari rumusan kata kerja "mengikatkan diri", sifatnya hanya datang dari satu pihak saja, tidak dari kedua belah pihak. Seharusnya rumusan itu ialah "saling mengikatkan diri" jadi ada konsensus antara dua pihak.

2) Kata perbuatan mencakup juga tanpa consensus: Dalam pengertian "perbuatan" termasuk juga tindakan penyelenggaraan kepentingan (zaakwaarneming), tindakan melawan hukum (onrechtmatige doad) yang 

3) tidak mengandung suatu konsensus. Seharusnya dipakai istilah "pesetujuan".

4) Pengertian tentang perjanjian terlalu luas: Pengertian tentang perjanjian juga mencakup tentang hal perjanjian kawin yang dlama KUHPer diatur dalam bidang hukum keluarga. Sedangkan dalam hal ini yang dimaksud adalah hubungan antara debitur dan kreditur mengenai harta kekayaan. Perjanjian yang diatur dalam buku III KUHPerdata sebenarnya hanya bersifat kebendaan, bukan bersifat kepribadian (personal).

5) Tanpa menyebut tujuan: Dalam rumusan pasal itu tidak disebutkan tujuan mengadakan perjanjian, sehingga pihak-pihak mengikatkan diri itu tidak jelas untuk apa. ${ }^{1}$

Mariam Darus Badrulzaman dalam hal ini, menyatakan bahwa: "Para Sarjana Hukum Perdata pada umumnya berpendapat bahwa defenisi perjanjian yang terdapat di dalam ketentuan di atas adalah tidak lengkap dan pula terlalu luas". Tidak lengkap karena dalam aturan ini yang dirumuskan hanya menyangkut hal perjanjian sepihak saja dan dikatakan terlalu luas karena juga mencakup perbuatan yang diatur dalam lapangan hukum keluarga, seperti janji kawin yang merupakan perjanjian juga tetapi sifatnya berbeda dengan perjanjian yang diatur dalam KUHPerdata Buku III. Perjanjian yang diatur dalam KUHPerdata Buku III kriterianya dapat dinilai secara materiil, dengan kata lain dinilai dengan uang. ${ }^{2}$

\subsubsection{Konsep Perjanjian Beli Kembali (Buy Back Guarantee)}

Menurut Suharnoko Suatu salah satu prinsip yang berlaku dalam lapangan hukum jaminan adalah bahwa dalam hal terjadi perjanjian jaminan Kreditur tidak dapat meminta perjanjian agar memiliki benda jaminan bagi pelunasan utang debitur kepada

${ }^{1}$ Abdulkadir Muhammad, Hukum Perikatan, Alumni, Bandung, 1982, hlm. 78.

${ }^{2}$ Mariam Darus Badrulzaman, dkk., Kompilasi Hukum Perikatan Dalam Rangka Memperingati Memasuki Masa Purna Bakti Usia 70 Tahun, Citra Aditya Bakti, Bandung, 2001, hlm. 65. 

kreditur, ketentuan ini untuk mencegah terjadinya ketidakadilan yang akan terjadi jika kreditur memiliki benda jaminan yang nilainya lebih besar dari jumlah hutang debitur kepada kreditur. ${ }^{1}$ karena itu benda jaminan tersebut harus dijual dan kreditur berhak mengambil uang hasil penjualan tersebut sebagai pelunasan piutangnya. Apabila masih ada kelebihan maka sisa hasil penjualan tersebut harus dikembalikan kepada debitur.

Dalam praktek pelaksanaan perjanjian kredit dengan jaminan kreditur berupaya mencari terobosan atas ketentuan-ketentuan dalam hukum jaminan, dalam hal ini pembuatan perjanjian jual beli dengan hak membeli kembali yang dilakukan adalah guna menyelubungi perjanjian utang piutang berikut tanah sebagai jaminannya. Sikap Mahkamah Agung Republik Indonesia dalam hal ini sudah jelas, yaitu: "membatalkan atau menyatakan batal demi hukum perjanjian seperti itu". Namun demikian mengingat berbagai kendala yang dihadapi oleh kreditur dalam melakukan eksekusi atas benda yang dijaminkan maka perlu dipikirkan suatu mekanisme hukum yang memungkinkan kreditur memperoleh pelunasan piutangnya secara efisien dengan tetap memberikan perlindungan hukum kepada debitur.

Buy Back guarantee menurut Dona Budi Kharisma², adalah perjanjian penjaminan, berbeda dengan hak membeli kembali sebagaimana diatur dalam pasal 1519 KUHP, sebenarnya dalam perjanjian buy back guarantee menimbulkan akibat hukum bagi pihak Debitur, Kreditur dan pennjamin yang obyeknya adalah pemenuhan prestasi yang menurut pasal 1234 KUHP Prestasi dapat berbentuk memberikan sesuatu, berbuat sesuatu tau tidak berbuar sesuatu maka penjamin mempunyai tanggung gugat yang sama dengan debitur yaitu membayar angsuran atau membeli kebali obyek jaminan bila debitur wan prestasi.

${ }^{1}$ Suharnoko, Hukum Perjanjian. Teori dan Analisa Kasus, Cetakan kedua, Prenada Media, Jakarta, 2004, hlm. 23.

${ }^{2}$ Dona Budi Kharisma, jurnal privat Law vol iii 2015 



\subsubsection{Asas Jaminan dalam Prinsip Kehatihatian Bank (Prudential Banking Principles)}

Penerapan prinsip kehati-hatian (prudential banking principles) dalam seluruh kegiatan perbankan merupakan salah satu cara untuk menciptakan Bank yang sehat dengan menerapkan asas Hukum jaminan menurut Suharnoko Seluruh harta benda Debitur demi hukum (by operation of law) menjadi jaminan bagi pelunasan utang Debitur kepada Kreditur, apabila harta benda debitur tidak mencukupi maka hasil penjualan harta benda debitur dibagikan secara proporsional menurut besar kecilnya piutang. ${ }^{1}$

Menganalisa kecukupan nilai jaminan adalah sebagian dari penerapan Prinsip kehati hatian bank, karena ada dasarnya dalam Undang undang Perbankan telah diatur dasar hukum penerapan Prinsip kehati hatian Bank adalah UU Perbankan / pasal 2 UU no 7 tahun 1992 "Perbankan Indonesia dalam melakukan usahanya berasaan demokrasi ekonomi dengan menggunakan prinsip kehati hatian"

Pasal UU no 10 tahun 1998 masih tentang perbankan dan Pasal 35 UU no 21 tahun 2008 yang keduanya menyatakan tentang keharusan pelaksanaan prinsip kehati hatian dalam operasional usaha perbankan di Indonesia yang semuanya harus dilaporkan kepada Bank Central Yaitu Bank Indonesia agar Bank Indonesia bisa menjalankan Fungsi pengawasannya

\section{Bentuk Perlindungan hukum bagi pengembang untuk memiliki kembali} obyek Jaminan jika pengembang melaksanakan isi dari Perjanjian Beli Kembali (buy Back Guarantee)

\subsection{Teori Perlindungan Hukum}

Perlindungan Hukum merupakan unsur yang harus ada dalam suatu negara, dalam setiap pembentukan negara pasti di dalamnya ada hukum unuk mengatur warga negaranya. Dalam suatu Negara, terdapat suatu hubungan antara negara dengan warga negaranya. Hubungan inilah yang

${ }^{1}$ Ibid., hlm. 24.

68. JURNAL TRANSPARANSI HUKUM Volume 1, Nomor 1, Januari 2018, Halaman 55-79 

melahirkan hak dan kewajiban. Perlindungan Hukum akan menjadi hak bagi warga negara, namun di sisi lain Perlindungan Hukum menjadi kewajiban bagi negara.

a. Menurut Satijipto Raharjo, "perlindungan hukum adalah memberikan pengayoman terhadap hak asasi manusia (HAM) yang dirugikan orang lain dan perlindungan itu di berikan kepada masyarakat agar dapat menikmati semua hak-hak yang diberikan oleh hokum". ${ }^{1}$

b. Menurut Maria Alfons, "Ada dua macam perlindungan hukum, yaitu perlindungan hukum preventif dan perlindungan hukum represif. perlindungan hukum yang preventif bertujuan untuk mencegah terjadinya sengketa, yang mengarahkan tindakan pemerintah berikap hati-hati dalam pengambilan keputusan berdasarkan diskresi, dan perlindungan yang represif bertujuan untuk menyelesaikan terjadinya sengketa, termasuk penangananya di lembaga peradilan". ${ }^{2}$

Pelaksanaan asas keterbukaan dalam pelaksanaan pemerintahan penting dilakukan, aturan-aturan tentang perlindungan hukum prefentif dalam hukum administrasi negara perlu segera mendapat perhatian. Perlindungan hukum preventif dilakukan melalui upaya peran serta (inspraak) ataupun dengar pendapat. Dalam hubungan ini asas keterbukaan dalam pelaksanaan pemerintahan sangat penting artinya. Arti penting perlindungan hukum preventif ialah mencegah sengketa adalah lebih baik daripada menyelesaikan sengketa. ${ }^{3}$ Pengaturan tentang sarana perlindungan hukum preventif dalam hukum administrasi positif kita belum memadai. Sehubungan dengan itu usaha kodifikasi hukum

${ }^{1}$ Satjipto Rahardjo, “IImu Hukum' Citra Aditya Bakti, Bandung, 2000, hlm. 54.

${ }^{2}$ Maria Alfons, Implementasi Perlindungan Indikasi Geografis Atas Produk-produk Masyarakat Lokal Dalam Perspektif Hak Kekayaan Intelektual, Ringkasan Disertasi Doktor, Universitas Brawijaya, Malang, 2010, hlm. 18.

${ }^{3}$ Philipus M. Hadjon, et.al., Hukum Administrasi dan Tindak Pidana Korupsi, Gadjah Mada University Press, Yogyakarta, 2011, hlm. 8-9. 

administrasi umum berupa undang-undang tentang ketentuan umum hukum administrasi akan sangat menunjang hal tersebut di atas.

Perlindungan hukum represif di Indonesia dewasa ini dilakukan melalui lembaga Pengadilan, dalam kaitan ini Rusli Muhammad menyatakan, sebagai sarana mengupayakan hukum, lembaga pengadilan pun merupakan tempat perlindungan hukum dan bagi warga negara maupun aparatur negara yang tersangkut dalam suatu sengketa hukum. Oleh sebab itu dapatlah dimaklumi keperluan akan adanya lembaga pengadilan yang baik, teratur serta memenuhi rasa keadilan masyarakat guna mewujudkan terselenggaranya negara hukum yang berdasarkan Pancasila. ${ }^{1}$ Perlindungan hukum merupakan suatu gambaran dari fungsi hukum yaitu bahwa hukum dapat memberikan suatu keadilan, ketertiban, kepastian, kemanfaatan, dan kedamaian.

\subsection{Teori Keadilan}

Teori tentang Keadilan telah dibicarakan oleh para filsuf sejak zaman Purbakala dengan tokoh pemikirnya antara lain Sokrates, Plato, Aristotelse dan filsuf-filsuf lainnya. Socrates dalam dialognya dengan Thrasymachus berpendapat: "bahwa dengan mengukur apa yang baik dan apa yang buruk, indah dan jelek, berhak dan tidak berhak jangan diserahkan semata-mata kepada orang perseorangan atau kepada mereka yang memiliki kekuatan atau penguasa yang zalim”. Ukuran-ukuran yang objektif perlu ditetapkan untuk menilainya. Soal keadilan hendaknya berlaku juga bagi seluruh masyarakat bukan hanya

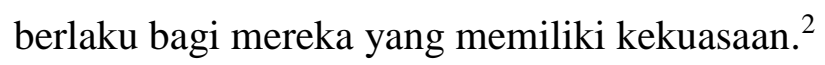

Plato mengartikan: "aturan negara yang adil dapat dipelajari dari aturan yang baik dari jiwa yang terdiri dari tiga bagian yaitu Pikiran (logistikon), perasaan atau nafsu, (epithumetikhon) dan bagian rasa baik atau jahat (thumoeides)". Dalam ketiga bagian tersebut dapat ditemukan unsur-unsur

\footnotetext{
${ }^{1}$ Rusli Muhammad, Lembagvd16dd8a Pengadilan Indonesia Beserta Putusan Kontroversial, UII Press, Yogyakarta, 2013, hlm. 3.

${ }^{2}$ Lili Rasjidi dan Ira Thania Rasjidi, Dasar-dasar Filsafat dan Teori Hukum, Citra Aditya Bakti, Bandung, 2007, hlm. 14.
} 

tentang keadilan. Demikian juga dengan Negara harus diatur dengan seimbang sesuai dengan bagian-bagiannya supaya adil. ${ }^{1}$ menurut Aristoteles ketaatan kepada hukum baik hukum yang tertulis maupun yang tidak tertulis merupakan bentuk keutamaan moral yang merupakan keutamaan tertinggi manusia yang pada akhirnya akan melahirkan bentuk keadilan. Dengan menjalankan keadilan ini, manusia mewujudkan keutamaan yang lain oleh karena segala yang lain dituntut oleh hukum Negara. Maka keadilan menurut hukum adalah sama dengan keadilan umum. ${ }^{2}$

Keadilan menurut aristoteles dibedakan kedalam dua jenis yaitu "keadilan distributif dan keadilan korektif'. Keadilan distributif berfokus pada distribusi honor, kekayaan dan barang-barang lain yang sama-sama bisa didapatkan oleh masyarakat. Distribusi yang adil dalam masyarakat merupakan bentuk distribusi yang sesuai dengan nilai-nilai kebaikannya bagi masyarakat. Sedangkan keadilan korektif berfokus pada pembetulan sesuatu yang salah. Jika suatu perjanjian dilanggar atau kesalahan dilakukan maka keadilan korektif berupaya memberikan kompensasi yang memadai bagi pihak yang dirugikan, jika suatu kejahatan dilakukan maka hukuman yang sepantasnya perlu diberikan kepada si pelaku. $^{3}$

\subsubsection{Pengertian SUBROGASI}

Kedudukan pengembang sebagai penjamin bisa menggantikan posisi kreditur jika pelaksanaan buy back guarantee di nyatakan melalui lembaga subrogasi. Sesuai dengan undang undang Hak tanggungan pasal 16 (1) jika piutang yang dijamin dengan hak tanggungan beralih karena cesie, subrogasi, pewarisan atau sebab sebab lain, Hak Tanggungan tersebut ikut beralih karena hukum kepada kreditur yang baru.

Dalam buku III KUHPerdata pasal 1400 "Subrogasi atau perpindahan hak kreditur kepada seorang pihak ketigayang membayar kepada jreditur, dapat terjadi karena persetujuan atau karena undang undang"

\footnotetext{
${ }^{1}$ Theo Huijbers, Filsafat Hukum dalam Lintasan Sejarah, Kanisius, Jakarta, 1982, hlm. 23.

${ }^{2}$ Ibid., hlm. 28-29.

${ }^{3}$ Carl Jachim Friedrich, Filsafat Hukum Perspektif Historis, Nuasa dan Nusamedia, Bandung, 2004, hlm. 24-25.
} 

Unsur unsur dalam Subrogasi

1. "Harus ada lebih dari 1 (satu) Kreditur dengan hanya 1 (satu) debitur yang sama sebagai subyek hukum".

2. "Adanya Pembayaran oleh Kreditur baru kepada kreditur lama".

Sifat Subrogasi menurut Obbie Afri Gultom adalah merupakan perjanjian accecoir , "perjanjian accecoir keberadaannya selalu mengikuti perjanjian pokoknya, perjanjian tersebut tersebut ikut beralih kepada kreditur baru mengikuti perjanjian pokoknya dimana utang piutang yang lama dihapus untuk kemudian dihidupkan lagi bagi kepentingan kreditur baru, jika timbul karena perjanjian harus menggunakan akta, dan harus dinyatakan dengan tegas agar kreditur baru mendapatkan hak penuh atas debitur".

\section{KESIMPULAN}

\subsection{Hubungan hukum dan tanggung gugat pihak pengembang, bank, dan} debitur dalam perjanjian beli kembali (buy back guarantee).

Hubungan hukum dan tanggung gugat pihak pengembang, bank, dan debitur/pembeli dalam perjanjian beli kembali (buy back guarantee), diuraikan sebagai berikut: Bahwa hubungan hukum antara Bank dengan debitur/pembeli yang melakukan pembelian unit rumah dengan fasilitas Kredit Pemilikan Rumah dari Bank diatur dalam perjanjian kredit dan/atau perjanjian pengakuan hutang dengan jaminan dan tanggung gugat Kreditur/Bank adalah memberikan fasilitas KPR kepada debitur dan tanggung gugat debitur adalagh membayar angsuran atau melunasi hutangnya kepada kreditur dalam hal ini pihak bank, sedangkan hubungan hukum yang terbentuk antara pihak bank dengan pengembang diatur dalam perjanjian buy back guarantie, perjanjanjian kerjasama yang terbentuk adalah bahwa dalam hal ini pengembang bertanggungjawab sebagai penjamin atas pembayaran angsuran dan atau seluruh jumlah uang yang terutang oleh debitur/pembeli kepada bank bila debitur/pembeli telah melalaikan kewajiban kepada bank, kemudian antara pengembang dengan debitur/pembeli hubungan hukum yang timbul tidak mengikat Debitur untuk 

membayar kepada pengembang karena kedudukan pihak ketiga dalam buy back guarantee tidak menggantikan posisi kreditur.

\subsection{Bentuk Perlindungan hukum bagi pengembang untuk memiliki kembali obyek Jaminan jika pengembang melaksanakan isi dari Perjanjian Beli Kembali (buy Back Guarantee)}

Perjanjian beli kembali merupakan bentuk perlindungan hukum bagi pengembang dalam proses perjanjian kredit dengan hak tanggungan, untuk memiliki kembali obyek jaminan jika pengembang melaksanakan isi dari perjanjian beli kembali (buy back guarantee), yang sesuai dengan asas Perlindungan hukum dan asa keadilan bahwa pengembang berhak atas rasa keamanan, hak untuk mendapat perlindungan hukum dari tindakan pembeli yang beritikad tidak baik; hak untuk melakukan pembelaan diri sepatutnya di dalam penyelesaian hukum sengketa konsumen. Agar tidak menciderai hunbungan kerjasama yang telah terjalin baik antara Bank dan pengembang dan kedudukan pengembang sebagai penjamin mampu menggantikan posisi Kreditur adalah melalui lembaga SUBROGASi

\section{SARAN}

11.1 Dalam penyaluran kredit diharapkan pihak bank selalu memperhatikan dan menerapkan prinsip kehati-hatian dan melakukan analisis kredit secara cermat, teliti dan mendalam dari berbagai aspek berdasarkan prinsip-prinsip yang berlaku secara universal dalam dunia perbankan. Hal ini dipandang perlu untuk menghindari atau mengantisipasi munculnya kredit bermasalah dikemudian hari.

11.2 Bagi pengembang agar lebih seksama menentukan calon pembeli unit-unit perumahan yang dipasarkannya, tidak hanya sekedar mengejar target pemasaran/terjualnya unit-unit perumahan yang dibangunnya. Karena jika developer hanya mengejar target pemasaran unit-unit perumahan saja akan berakibat permasalahan apabila ternyata kredit kepemilikan rumah yang diberikan bank kepada debitornya mengalami kemacetan. 

11.3 Bagi Praktek Kenotariatan dihimbau agar mampu memberikan konsultasi hukum yang transparan kepada para pihak dalam akta beli kembali (buy back guarantee) dan melengkapinya dengan akta Subrogasi 



\section{DAFTAR BACAAN}

\section{Buku:}

Abdulkadir Muhamad, Hukum Perdata Indonsia, Citra Aditya Bakti, Bandung, 1990.

Abdulkadir Muhammad, Hukum Perikatan, Alumni, Bandung, 1982.

Achmad Ichsan, Hukum Perdata IA, Pembimbing Masa, Jakarta, 1970.

Anita Kamilah, Bangun Guna Serah (Build Operate and Transfer/Bot) Membangun Tanpa Harus Memiliki Tanah (Perspektif Hukum Agraria, Hukum Perjanjian dan Hukum Publik), Penerbit Keni,Bandung, 2012.

Ari Purwadi, Problematika Hak tanggungan Menurut Undang-Undang Nomor 4 Tahun 1996, Jurnal Hukum Ekonomi, Edisi IX Agustus 1997.

Ariadin Nadjamuddin, Aspek Hukum Akta Buy Back Guarantee dan Implikasinya bagi Lembaga Perbankan, Tesis Program Pasca Sarjana Magister Kenotariatan PPs Universitas Hasanudin Makasar, 2012.

Bloembergen, A.R., et.al., Rechtshandeling en Overeenkomst, Deventer, 1995.

Carl Jachim Friedrich, Filsafat Hukum Perspektif Historis, Nuasa dan Nusamedia, Bandung, 2004.

Djaja S. Meliala, Hukum Perdata dalam Perpektf BW, Nuansa Aulia, Bandung, 2014.

Djuhaendah Hasan, Lembaga Jaminan Kebendaan Bagi Tanah dan benda Lain Yang Melekat Pada Tanah Dalam Konsepsi Penerapan Asas Pemisahan Horisontal, Nuansa Madani, Jakarta, 2011.

H.F.A. Vollmar, Pengantar Studi Hukum Perdata, Jilid II, Rajawali, Jakarta, 1984.

H.P. Pangabean, Praktik Standard Contract (Perjanjian Baku) Dalam Perjanjian Kredit Perbankan), Alumni, Bandung, 2012.

Hardijan Rusli, Hukum Perjanjian Indonesia dan Common Law, Sinar Harapan, Jakarta, tanpa tahun.

Herlien Budiono, Asas Keseimbangan bagi Hukum Perjanjian Indonesia, Hukum Perjanjian Berlandaskan Asas-asas Wigati Indonesia, Citra Aditya Bakti, Bandung,2006. 

Herowati Poesoko, Herowati Poesoko, Parate Executie Obyek Hak Tanggungan (Inkonsistensi, Konflik Norma dan Kesesatan Penalaran Dalam UUHT), Laksbang PRESSindo, Yogyakarta, 2007.

Irawan Soerodjo, Hukum Perjanjian dan Pertanahan: Perjanjian Build, Operate and Transfer (Bot) atas Tanah, Pengaturan Karakteristik dan Praktik, Laksbang Pressindo, Yogyakarta, 2016.

J. Satrio, Hukum Jaminan, Hak Jaminan Kebendaan, Hak Tanggungan Buku 2, Citra Aditya Bakti, Bandung, 2004.

Kristina Novi Nugroho Proborini "Tinjauan Yuridis terhadap Perjanjian Buy Back Guarante terhadap Kredit Kepemilikan Rumah pada PT,Bank Tabungan Negara (Persero Tbk.) Cabang Banjarmasin" Magister Kenotariatan Universitas Gajah Mada Jogjakarta, Tahun 2012.

Lili Rasjidi dan Ira Thania Rasjidi, Dasar-dasar Filsafat dan Teori Hukum, Citra Aditya Bakti, Bandung, 2007.

Moch. Isnaeni, Hak Tanggungan Sebagai Lembaga Jaminan Dalam Kerangka Tata Hukum Indonesia, Jurnal Hukum Ekonomi, Edisi V, Agustus 1996.

Moch. Isnaeni, Hukum Jaminan Sebagai Sarana Pendukung Ekonomi, Hukum Ekonomi, Agustus, 1995.

Moch. Isnaeni, Pengantar Hukum Jaminan Kebendaan, Revka Petra Media, Surabaya, 2016.

M. Yahya Harahap, Segi-segi Hukum Perjanjian, Alumni, Bandung, 1992.

Maria Alfons, Implementasi Perlindungan Indikasi Geografis Atas Produk-produk Masyarakat Lokal Dalam Perspektif Hak Kekayaan Intelektual, Ringkasan Disertasi Doktor, Universitas Brawijaya, Malang, 2010.

Mariam Darus Badrulzaman, Aneka Hukum Bisnis, Alumni, Bandung, 1994.

Mariam Darus Badrulzaman, dkk., Kompilasi Hukum Perikatan Dalam Rangka Memperingati Memasuki Masa Purna Bakti Usia 70 Tahun, Citra Aditya Bakti, Bandung, 2001.

Mariam Darus Badrulzaman, KUHPerdata Buku III Hukum Perikatan dengan Penjelasan, Almni, Bandung, 1996.

Munir Fuady, Hukum Kontrak (Dari Sudut Pandang Hukum Bisnis), Citra Aditya Bakti, Bandung, 2001. 

Munir Fuady, Konsep Hukum Perdata, Radja Grafindo Persada, Jakarta, 2014.

P.N.H. Simanjuntak, Pokok-pokok Hukum Perdata Indonesia, Djambatan, Jakarta, 2009.

P.S. Atiyah, An Introduction to the Law of Contract, Oxford University Press Inc., New York 1995.

Panary Sitopu, "Perjanjian Kerjasama antara Developer dengan Bank dalam Pemberian Fasilitas Kredit Kepemilikan Rumah, (Suatu Penelitian di PT, CIMB Niaga Tbk Cabang Medan Bukit Barisan), Tesis, Fakultas Hukum Universitas Sumatera Utara, Medan, 2010.

Peter Mahmud Marzuki, Penelitian Hukum, Edisi Revisi, Kencana Prenada Media Group, Jakarta, 2013.

Philipus M. Hadjon, et.al., Hukum Administrasi dan Tindak Pidana Korupsi, Gadjah Mada University Press, Yogyakarta, 2011.

R. Setiawan, Pokok-pokok Hukum Perikatan, Bina Cipta, Bandung, 1978.

R. Soeroso, Perjanjian di Bawah Tangan; Pedoman Praktis Pembuatan dan Aplikasi Hukum, Sinar Grafika, Jakarta, 2011.

R. Subekti \& R. Tjitrosudibio, Kitab Undang-Undang Hukum Perdata (Burgelijk Wetboek), Pradnya Paramita, Jakarta, 1992.

R. Subekti, Hukum Perjanjian, Intermasa, Jakarta, 1987.

R.M. Suryodiningrat, Asasasas Hukum Perikatan, Tarsito, Bandung, 1985.

Riduan Syahrani, Seluk Beluk dan Asas-asas Hukum Perdata, Alumni, Bandung, 1985.

Rusdianto Sesung, Prinsip Kesatuan Hukum Nasional dalam pembentukan Produk Hukum Pemerintah daerah Otonomi Khusus atau Istimewa, Proposal Disertasi Program Pasca Sarjana Unibersitas Airlangga Surabaya, 2016.

Rusli Muhammad, Lembaga Pengadilan Indonesia Beserta Putusan Kontroversial, UII Press, Yogyakarta, 2013.

Salim H.S., dkk., Perancangan Kontrak dan Memorondum of Understanding, Sinar Grafika, Jakarta, 2008.

Salim H.S., Hukum Kontrak dan Teknik Penyusunan Kontrak, Sinar Grafika, Jakarta, 2003. 

Salim HS, Perkembangan Hukum Jaminan Di Indonesia, Rajawali Pers, Jakarta, 2011.

Satjipto Rahardjo, “IImu Hukum'Citra Aditya Bakti, Bandung, 2000.

Sri Soedewi Masjchoen Sofwan, Hukum Jaminan Di Indonesia Pokok-pokok Hukum Jaminan Dan Jaminan Perorangan, Badan Pembinaan Hukum Nasional Departemen Kehakiman, Liberty, Yogyakarta, 1980.

Sri Soedewi Masjchoen Sofwan, Hukum Perutangan IA (Terjemahan Dari Buku Inleiding Nederlands Burgerlijk Recht dari HFA. Vollmar, Seksi Hukum Perdata Fakultas Hukum, UGM, Yogyakarta, 1975.

Sudikno Mertokusumo, Mengenal Hukum, Liberty, Yogyakarta, 1988.

Suharnoko, Hukum Perjanjian. Teori dan Analisa Kasus, Cetakan kedua, Prenada Media, Jakarta, 2004.

Sutan Remy Sjahdeini, Kebebasan Berkontrak dan Perlindungan yang Seimbang bagi Para Pihak dalam Perjanjian Kredit Bank di Indonesia, Institut Bankir Indonesia, Jakarta, 1993.

Theo Huijbers, Filsafat Hukum dalam Lintasan Sejarah, Kanisius, Jakarta, 1982. A.A. Andi Prajitno, Hukum Fidusia Problematika Yuridis Pemberlakuan Undang-Undang No. 42 Tahun 1999, Bayumedia Publishing, Malang, 2009.

Van Dale, Groot Woordenboek der Nederlandse Taal, Tiende Druk, Utrecht/Antwerpen, 1982.

Wirjono Prodjodikoro, Asas-asas Hukum Perdata, Cetakan Ketujuh, Sumur Bandung, Bandung, 1979 